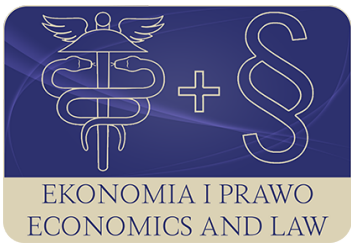

EKONOMIA I PRAWO. ECONOMICS AND LAW

Volume 20, Issue 1, March 2021

p-ISSN 1898-2255, e-ISSN 2392-1625

www.economicsandlaw.pl

EKONOMIA I PRAWO
ECONOMICS AND LAW

ORIGINAL ARTICLE

received 17.12.2019; revised 25.05.2020; accepted 31.03.2021

Citation: Woźniak, K. (2021). Indexes of migration policy restrictiveness: concept, methodology and application. Ekonomia i Prawo. Economics and Law, 20(1): 191-207.

doi:10.12775/EiP.2021.012.

\title{
Indexes of migration policy restrictiveness: concept, methodology and application
}

\author{
KATARZYNA WOŹNIAK \\ Poznań University of Economics and Business, Institute of Economics, Department \\ of Macroeconomics and Development Research, al. Niepodległości 10, 61-875 Poznań, Poland \\ 曰 katarzyna.wozniak@ue.poznan.pl \\ (D) orcid.org/0000-0002-9077-328X
}

\begin{abstract}
Motivation: migration management has become important both in the political debate and academic research. In recent years the interest of researchers in migration policy has significantly increased. As a result, there have been many quantitative studies related to the migration policy.

Aim: the aim of this paper is to conduct a comparative analysis of the migration policy indexes (including databases on migration policies), as well as to broaden the understanding of the scope and essence of migration policies.

Results: The indexes of migration (including immigration) restrictiveness are based on various concept of this policy. However, all the indexes of migration (including immigration) restrictiveness are based on de jure migration laws and regulations measures adopted by states (on the national level). The most of indexes of migration (including immigration) policy restrictiveness are based on a set of coded questions relating to these policies. An important factor differencing the migration policy indexes is also the fact that in some analyses relative changes of migration policy were evaluated, but in other studies absolute changes were considered. Concerning to the indexes of immigration restrictiveness, most of them are based on entry and stay regulations. The possible application of indexes in other studies is especially related to the time and geographical scope of these indexes, as well as to their level of detail. Most of the data on migration policies is available mainly for the developed countries, the majority of which belongs to the OECD or the European Union. Some of them allow for the long-term analysis and other for shortterm study. For most countries the data is available since the 1980s. Additionally, some
\end{abstract}


of indexes on immigration policy restrictiveness are characterised by relative higher level of detail of the analysis and results are classified for various groups of migrants and type of migration.

Keywords: international economics; immigration policy; migration policy; migration policy indexes JEL: F22; K37

\section{Introduction}

One of the key activities of the 2030 Sustainable Development Agenda adopted by world leaders is migration. In recent years, international organizations, governments and other actors are engaged in efforts to research on the scale and characteristics of migration globally (International Organization for Migration, 2018, p. 40). Migration management has also become important both in the political debate and academic research.

The research on migration policy is particularly focused on descriptive characteristics. However, in recent years the interest of researchers in migration policy has significantly increased. In the course of the research on migration policy restrictiveness various databases and indexes were created. These studies are related to migration policy: the DEMIG (The determinants of international migration: a theoretical and empirical assessment of policy, origin and destination effects) project (de Haas et al., 2014) and the research by Rayp et al. (2017), as well as immigration policy: the index of strictness of migration policies of the Fondazione Rodolfo Debenedetti (2019) (see Fumagalli \& Boeri, 2009), the index of restrictiveness of migration policy by Ortega \&Peri (2009), the IMPIC project (Bjerre et al., 2016) and the IMPALA project (Gest et al., 2014).

The aim of this paper is to conduct a comparative analysis of the indexes of migration policy restrictiveness (including databases on migration policies), as well as to broaden the understanding of the scope and essence of migration policies. The concept, construction and methodology of migration policy indexes will be evaluated. What is more, the possible application of the migration policy indexes in other studies will also be discussed. Finally, the main differences and similarities between migration policy indexes will be identified. As a consequence, the analysis will be useful and helpful in the future research on migration flows and migration policy.

\section{Literature review}

Migration is a process that can be managed, while the migration policy is an integral part of the system of migration flows (Skeldon, 2010, p. 22, 30). The essence of migration policy boils down to three fundamental aspects: capacity for analysis and long-term forecast of the effects of the introduced migration policy rules, political capacity for reaching a consensus related to long-term objectives of migration policy, and tools that allow to achieve these goals with respect to democracy and the rule of law (Castles, 2006, p. 856). 
Therefore, the migration policy is a set of instruments developed and maintained by the state and it includes passive and active forms of migration management (Duszczyk, 2008, p. 12). It needs to be stressed that the migration policy includes immigration policy (including, in particular integration policy) and emigration policy (Duszczyk, 2014, pp. 39-40). In turn, international migration policies include legal provisions and regulations developed and implemented by individual states, that have direct and indirect impact on the scale and structure of migration flows (Czaika \& de Haas, 2013, p. 489).

In the course of the research on migration policy restrictiveness various databases and indexes were created. These studies are related to migration policy: the DEMIG project (de Haas et al., 2014) and the research by Rayp et al. (2017), as well as immigration policy: the index of strictness of migration policies of the Fondazione Rodolfo Debenedetti (2019) (see Fumagalli \& Boeri, 2009), the index of restrictiveness of migration policy by Ortega \& Peri (2009), the IMPIC project (Bjerre et al., 2016) and the IMPALA project (Gest et al., 2014).

DEMIG is one of the largest international projects on migration policy. This project includes more than 6,500 changes of migration policy (International Migration Institute, 2019). In other project titled Economic and social consequences of immigration, Rayp et al. (2017) constructed the Migration Policy Index, based on three sub-indexes. These indexes are based on all publicly available measures of migration policy.

Concerning to immigration policy, the index of strictness of migration policies is based on the data collected by the Fondazione Rodolfo Debenedetti (2019). This index is especially based on economic immigration (Fumagalli \& Boeri, 2009). The restrictiveness of immigration policy was also a subject of the research by Ortega \& Peri $(2009$, p. 2) who studied the changes of immigration policy restrictiveness, as well as the impact of the level of immigration policy restrictiveness on migration flows.

The next project titled The immigration policies in comparison was implemented by Bjerre et al. (2016). The aim of the IMPIC project is to evaluate the level of immigration policy restrictiveness and to develop the set of immigration policy indexes in various areas of this policy (Bjerre et al., 2016, p. 23). The IMPALA (International migration policy and law analysis) project is the international study on immigration policy and is led by researches from George Mason University, Harvard University, London School of Economics and Political Science, Paris School of Economics, University of Amsterdam, University of Luxembourg and University of Sydney (Gest et al., 2014). The aim of the IMPALA project is to create a database on changes in immigration policies that will allow to analyse patterns and trends of this policy, as well as to examine the restrictiveness of migration policy instruments with regard to various types of migration flows (Beine et al., 2016, pp. 828-829, 833-836; Gest et al., 2014, pp. 261-262, 265). 


\section{Methods}

The analysis is based on the wide range of migration policy. The study includes the international migration policy databases and indexes on migration policy restrictiveness. The systematic literature review will be used as a research method. The study will apply the combined methods of descriptive and comparative analysis of databases and indexes on migration policy.

The analysis is based on the two approaches to comparative research: features differ from each other in identified features interesting to the researcher and features are characterised by certain identified and described similarities. These approaches were suggested by Cheng (1984). First, the comparative analysis is based on the assumption that indexes on migration (including immigration) policy differ from each other in the following identified features: the concept of migration (including immigration) policy in the quantitative research; the methodology of indexes of migration (including immigration) policy restrictiveness (including: the kind of measurement methods of migration (including immigration) policy; the kind of changes assessed in research on migration (including immigration) policy restrictiveness); the components of indexes of migration (including immigration) policy restrictiveness and the possible application of indexes of migration (including immigration) policy restrictiveness in other studies (including: the time \& geographical scope and the level of detail). In the research, similarities between indexes on migration (including immigration) policy were also identified and described.

How is the concept of migration policy understood in the quantitative research on migration policy? What are the methodological assumptions of the migration policy indexes? What kind of measurement methods of migration policy and its main aspects are implemented in the literature? In this paper, I address these and other questions using research tools, in particular, the comparative and descriptive analysis.

\section{The concept of migration (including immigration) policy in the quantitative research on this policy}

As pointed in the second section of this paper, the migration policy includes immigration policy (including, in particular integration policy) and emigration policy. Some of the research on migration policy restrictiveness are based on migration policy and other only on immigration policy. The following indexes and projects are based on migration policy restrictiveness: the Migration Policy Index (MPI ${ }^{\mathrm{C}}$ ) by Rayp et al. (2017) and the DEMIG database ${ }^{1}$ (International Migration Institute, 2019). While, the following indexes and projects are

1 The DEMIG project is based on databases created by Mayda \& Patel (2004) and Hatton (2009). These databases analysed the main migration policy changes with the aim to study the regime of migration policy (i.e. relative migration policy changes (de Haas et al., 2015, p. 3). 
based on immigration policy restrictiveness: the index of strictness of migration policies of the Fondazione Rodolfo Debenedetti (2019) (see Fumagalli \& Boeri, 2009), index of restrictiveness of migration policy by Ortega \& Peri (2009), the IMPIC project (Bjerre et al., 2016) and the IMPALA project (Gest et al., 2014).

Concerning to the indexes and projects that are based on migration policy restrictiveness, both in DEMIG project and research conducted by Rayp et al. (2017), the public data sources related to the migration policy restrictiveness (de jure migration laws and regulations measures adopted by states) were implemented. These studies are based on 'policy on paper'. Additionally, in the DEMIG project it was assumed that migration policy includes rules (i.e. regulations, laws, measures) that states enact and define with the aim to influence the origin, direction, volume and internal composition of migration (de Haas et al., 2014, pp. 6-9; 2015, pp. 3-4, 6; Rayp et al., 2017, pp. 5-7).

However, in DEMIG project the authors additionally analysed some aspects of the political discourse (i.e. strategies and plans), and they included some international regulations, especially those associated with membership in the European Union (de Haas et al., 2014, pp. 6-9; 2015, pp. 3-4, 6). It needs to be also stressed that the Migration Policy Index $\left(\mathrm{MPI}^{\mathrm{C}}\right)$ not includes laws and regulations associated with asylum policy (Rayp et al., 2017, pp. 5-7), as opposed to DEMIG project.

Similarly, the all of analysed indexes on immigration policy (i.e. indexes constructed by the Fondazione Rodolfo Debenedetti (2019) and Ortega \& Peri (2009), IMPIC database and IMPALA database) are based on formal (de jure) regulations on immigration policies (Beine et al., 2016, pp. 828-829, 833-836; Bjerre et al., 2016, pp. 10-12; Fumagalli \& Boeri, 2009; Gest et al., 2014, pp. 261-262, 265; Ortega \& Peri, 2009, pp. 8-9). These indexes and databases include the regulations on the national level. In the IMPIC project, the European Union directives were also included (Bjerre et al., 2016, pp. 10-12).

\section{The methodology of indexes of migration (including immigration) policy restrictiveness}

\subsection{The kind of measurement methods of migration (including immigration) policy}

In the course of the research on migration (including immigration) policy restrictiveness various methods were implemented. In particular, the most of indexes of migration (including immigration) policy restrictiveness are based on a set of coded questions relating to these policies. The exception is the overall Migration Policy Index $\left(\mathrm{MPI}^{\mathrm{C}}\right)$ and its the three sub-indexes (respectively: $\mathrm{MPI}^{\mathrm{E}}$, $\mathrm{MPI}^{\mathrm{S}}$, MPI ) by Rayp et al. (2017). The calculations of the three sub-indexes were based on a Bayesian-state space model. The overall Migration Policy Index 
$\left(\mathrm{MPI}^{\mathrm{C}}\right)$ was calculated as arithmetic mean of all the values of three sub-indexes (i.e. $\left.\mathrm{MPI}^{\mathrm{E}}, \mathrm{MPI}^{\mathrm{S}}, \mathrm{MPI}^{\mathrm{I}}\right)^{2}$. The construction of these indexes are based on all publicly available measures of migration policy ${ }^{3}$ (Rayp et al., 2017, pp. 5-7, 9-11).

The second exception is the DEMIG database. DEMIG is especially based on descriptive statistics ${ }^{4}$. The particular changes of migration policy were coded only to one area of migration policy, however, the coding is not hierarchical and a change of migration policy may be coded to more than one of migration policy area (de Haas et al., 2014, pp. 11-19; 2015, pp. 8-10).

It needs to be stressed that, the main differences between the indexes of migration (including immigration) policy restrictiveness are also related to the system of coding adopted in a given research. The IMPIC project, the indexes constructed by Ortega \& Peri (2009) and IMPALA database are based on similar system of coding. However, some differences between these indexes can be also identified.

In the IMPIC project, each indicator (regulation) has values from 0 (liberal) to 1 (restrictive) (Bjerre et al., 2016, pp. 8-10, 17-18). It needs to be stressed that the missing values of the IMPIC index for a given country (e.g. when co-ethnics regulations are not implemented in a given country), should be interpreted as the highest level of immigration policy restrictiveness. For that reason, these regulations indicate that this migrant track is not implemented in the immigration law in a given country (Schmid \& Helbing, 2016, p. 15).

Concerning to the indexes constructed by Ortega \& Peri (2009, pp. 8-9), the reference year 1980 was adopted, in this year for each variable 0 was assumed. In the next step, it was assessed whether the change of regulations was more or less restrictive. If the change was assessed as more restrictive, the value of variable for a given country and year was lowered by 1 . If the change was assessed as less restrictive, the value of variable for a given country and year was raised by 1. The country entry regulations were identified as liberal in the following cases: if requirements related to a legal entry and obtaining a work or stay permit were less restrictive and more temporary permits were introduced. The country entry regulations were identified as more restrictive in the following cases: if a quota

2 The interpretation of the sub-indexes and the Migration Policy Index is as follows: the higher the level of sub-indexes or index, the lower the level of migration policy restrictiveness (Rayp et al., 2017, p. 11, 14).

3 The following publicly measures of migration policy are included: the Migrant Integration Policy Index, the Multiculturalism Policy Index, the component of the Commitment to Development Index - CDI, i.e. international students enrolled in tertiary education as a percentage of total enrolled students in tertiary education and data on migration policy from another papers (i.a. Mayda \& Patel, 2004; Ortega \& Peri, 2009; Rayp et al., 2017, pp. 42-44).

4 This project includes more than 6,500 changes of migration policy. The changes on migration policy include the type and short description of the adopted migration policy instruments for a given country (see: point 6 in this paper; de Haas et al., 2014, p. 4; 2015, pp. 2-3; International Migration Institute, 2019). 
system was introduced or a quota system was lower and the requirements of a legal entry and obtaining a work or stay permit were less liberal. The country residence regulations were identified as liberal in the following cases: if the number of required years to obtain permanent residence was lower and activities aimed to improve migrant integration were introduced. The country residence regulations were identified as more restrictive in the following cases: if the number of years required to obtain a permanent residence was higher or country residence restrictions were introduced. The same methodology was introduced in the process of assessment of regulations for asylum seekers.

The IMPALA project is also based on a set of coded questions relating to immigration policies (Beine et al., 2016, pp. 828-829, 833-836; Gest et al., 2014, pp. 261-262, 265). The most of regulations are coded as binary variables, where 1 means higher the level of immigration policy restrictiveness. Additionally, some results of the analysis have values between 0 and 1 (for example 0.33). These results were calculated as arithmetic mean of two or three the values of components ${ }^{5}$ (Beine et al., 2016, pp. 17-18).

The coding system in the research by the Fondazione Rodolfo Debenedetti (2019) is especially based on the number of particular components of index (for example: the number of certificates and procedures required to legally entry a country). The six areas were initially expressed either in various units or in an ordinal scale. In order to ensure the comparability, those measures were converted in cardinal scores and normalized to a range from 0 to 6 . The higher the level of index, the higher the level of migration policy restrictiveness. The value of overall index of strictness of migration policies was calculated as an average of six dimensions and index of strictness of asylum legislation constructed by Hatton (2004) (Fumagalli \& Boeri, 2009). The reform of migration policy was identified as liberal in the following cases: if its requirements related to a legal entry and residence permit were less restrictive, if the number of years required to obtain a permanent residence was lower and, if it aimed to improve the migrant integration. The reform of migration policy was identified as more restrictive in the following cases: if the quota system was introduced, if requirements of entry and stay in a given country were more restrictive, if the number of years required to obtain a permanent residence was higher and if additional requirements on residence were introduced (Fumagalli \& Boeri, 2009).

\subsection{The kind of changes assessed in research on migration (including immigration) policy restrictiveness}

In the course of the research on migration (including immigration) policy restrictiveness various kind of changes of this policy (relative or absolute) were

5 The IMPALA project is still in progress and the detailed data on immigration policies is not available. As a result of the pilot study, only a part of the findings was published so far (Gest et al., 2014). The examples of coding it can be find in the pilot study (see: Beine et al., 2016). 
also assessed. The most of the research on migration (including immigration) policy restrictiveness are included data on absolute level of these policies. These research included: indexes by the Fondazione Rodolfo Debenedetti (2019) (see Fumagalli \& Boeri, 2009), the IMPIC project (Bjerre et al., 2016), the sub-indexes and the Migration Policy Index by Rayp et al. (2017) and the IMPALA project (Gest et al., 2014). In these research absolute level of the restrictiveness of migration (including immigration) policy instruments was examined.

While, the DEMIG database and the indexes by Ortega \& Peri (2009) are included data on relative level of these policies. The DEMIG database includes data on relative level of migration policy changes (the assessment of absolute level of migration policy is not included in this project) (de Haas et al., 2014, pp. 14-15; 2015, p. 12). Similarly, the construction of indexes by Ortega \& Peri $(2009$, p. 2) is based on changes in immigration regulations in the host countries. Each change of migration policy was assessed based on the fact whether the change was more or less restrictive in the previous period.

\section{The components of indexes of migration (including immigration) policy restrictiveness}

The main difference among indexes on migration policy is various areas of this policy that adopted by individual researchers. Both in the DEMIG project and research conducted by Rayp et al. (2017) the following areas of migration policy were included: legal entry and stay ${ }^{6}$ and integration ${ }^{7}$. Additionally, the DEMIG database is also included the two areas of migration policy: border control $^{8}$ and emigration ${ }^{9}$ (table 1 and 2) (de Haas et al., 2014, p. 23; 2015, pp. 5-6; Rayp et al., 2017, pp. 9-11).

Apart from this, in the DEMIG project the following aspects were also identified $^{10}$ : the type of tool of migration policy (28 migration policy tools were identified), magnitude of change (major, mid-level, minor, fine-tuning), target group (e.g.: skilled immigrants, total 14 groups were identified), origin of migrants (5 categories), level of legislation (national or multi- or bilateral national)

${ }^{6}$ Both in the DEMIG project (de Haas et al., 2014, p. 23) and the research by Rayp et al. (2017, pp. 9-11) the legal stay and entry includes all instruments of migration policy concerning the residence and entry permit (including permanent and temporary residence).

7 In the DEMIG project, the integration concerns tools of migration policy that regulate migrant rights in the host countries and relationship between migrants and diaspora, while in the research by Rayp et al. (2017, pp. 9-11) mainly — immigrants' rights (de Haas et al., 2014, p. 23).

8 Border control includes tools of migration policy and mainly relates to the control of internal and external country borders (de Haas et al., 2014, p. 23).

9 The regulations on emigration that are related to the voluntary and enforced return (de Haas et al., 2014, p. 23).

10 As pointed earlier, the DEMIG project is especially based on descriptive statistics. 
and restrictiveness of migration policy change (table 1) (de Haas et al., 2014, pp. 11-19; 2015, pp. 8-10).

The main difference among indexes on immigration policy is also various areas of this policy that adopted by individual researchers. Most of indexes are included the following area of immigration policy: entry and stay rules. The immigration policy of all analysed indexes (i.e. indexes constructed by the Fondazione Rodolfo Debenedetti (2019) and Ortega \& Peri (2009), IMPIC database and IMPALA database) is based on entry and stay regulations. However, the index of strictness of migration policies by the Fondazione Rodolfo Debenedetti (2019) is only based on regulations on economic immigration ${ }^{11}$.

The most areas of immigration policy were identified in the IMPIC project and IMPALA database. In these projects, the following areas of immigration policy are also included: family reunion and economic (labour) migration. Additionally, in the IMPIC project immigration control ${ }^{12}$ and political and social rights of immigrants were also included. In turn, the IMPALA database is also included regulations concerning the access to nationality (table 1 and 2) ${ }^{13}$.

In some research, entry and stay rules are classified for various groups of migrants, in the project by Ortega \& Peri (2009), IMPIC project and IMPALA database for asylum seekers, in the IMPIC project for refugees and ethnic groups and in the IMPALA database for humanitarian migrants and international students. Additionally, in the IMPIC project the following groups of migrants were also included: in the area of labour migration the following groups of migrants were identified: low-skilled immigrants, highly-skilled immigrants, self-employed immigrants and other; in the area of family reunion the regulations were divided into those that were related to nationals of a given country that apply for family reunification and third-country nationals that apply for family reunification; in the last area - ethnic group four migrant tracks were identified that related to migration for historic and cultural reasons. However, only $1 / 3$

${ }^{11}$ The index of strictness of migration policies is based on six components on economic immigration: the number of certificates and procedures required to legally entry a country, the number of certificates and procedures needed to legally stay in a given country (the differences between those components are related to the fact that in many cases holding a valid document required for a legal entry was not enough to obtain a legal residence; e.g. obligation of own financial assets for livelihood), the number of years needed to obtain a permanent residence, necessity of holding two separate work and residence permits or only one permit — both for work and residence, requirements related to the first residence permit (necessity of holding this permit before or after an entry to a given country) and occurrence of a quota system or lack of it (Fumagalli \& Boeri, 2009).

12 This area concerns the control mechanisms that aimed to prevent immigrant regulation of other areas of immigration policy and illegal immigration regulations (e.g. sanctions against employer who hire illegal immigrants) (Bjerre et al., 2016, pp. 5-6, 44; Helbling et al., 2017, p. 85; Schmid \& Helbing, 2016, p. 5).

${ }^{13}$ However, this project does not include integration which is the key subject of another study, i.e. MIPEX (2015). 
of the analysed countries implemented the co-ethnics regulations in their immigration policy (Schmid \& Helbing, 2016, p. 6).

Certainly, the IMPIC project is characterised by the most level of detail of the analysis on immigration policy restrictiveness (table 1 ). In each of the identified areas of immigration policy the regulations (including those related to four areas of immigration policy and control mechanisms) were divided into internal and external aspects (Bjerre et al., 2016, pp. 6-7; Schmid \& Helbing, 2016, pp. 5-6). Additionally, the internal regulations were also divided into the following aspects: 'security of status' (this category is related to obtaining a permit for stay and its length) and 'rights associated' (immigrant's access to rights). The external regulations were divided into two categories: 'eligibility' (this category is related to requirements for entry immigrants) and 'conditions' (including additional requirements of immigration) (Helbling et al., 2017, p. 85).

\section{The possible application of indexes of migration (including immigration) policy restrictiveness in other studies}

\subsection{The time and geographical scope}

The possible application of indexes in other studies is especially related to the time and geographical scope of these indexes. Coded data on relative changes in migration policies comes from 1945 (mostly in the years 1945-2013; see: DEMIG database, table 1) (de Haas et al., 2014, p. 4; 2015, pp. 2-3; International Migration Institute, 2019). However, for most countries the data is available since the 1980s. The indexes by Ortega \& Peri $(2009$, p. 2) were constructed in the years 1980-2005, the IMPIC and IMPALA database includes data in the years 1980-2010 (Beine et al., 2016, pp. 827-828, 837-838; Bjerre et al., 2016, p. 4). While, the index by the Fondazione Rodolfo Debenedetti (2019) was constructed for the years 1990-2005 and the indexes by Rayp et al. (2017, p. 11, 14) were estimated for the years 1996-2014 (table 1).

Most of the data on migration policies is available mainly for the developed countries, the majority of which belongs to the OECD or the European Union. In particular, the DEMIG project includes changes of migration policy introduced by 45 countries (most of them are the OECD countries), the IMPALA dataset includes data for countries that belong to the OECD, except economies with negative net migration over the past 20 years, the indexes by Rayp et al. (2017) were estimated for all the OECD membership, excluding: Chile, Israel and Mexico in the years 1996-2014, the IMPIC database includes data for the 33 OECD countries and indexes by Ortega \& Peri (2009) were constructed for the 14 OECD countries. While, the index by the Fondazione Rodolfo Debenedetti (2019) was constructed for 12 countries that belong to the EU (Beine et al., 2016, pp. 827-828, 837-838; Bjerre et al., 2016, p. 4; de Haas et al., 2014, p. 4; 2015, pp. 2-3; Fumagalli \& Boeri, 2009; Gest et al., 2014; Interna- 
tional Migration Institute, 2019; Ortega \& Peri, 2009, p. 2; Rayp et al., 2017, p. 11, 14).

\subsection{The level of detail}

The possible application of indexes in other studies is also related to their level of detail. Certainly, the all of the analysed indexes may be a useful tool to perform the qualitative and quantitative study. However, some of them allow for the long-term analysis and other for short-term study. For example, as the authors of the DEMIG project point out, the DEMIG dataset allows for the study on the long-term evolution, as well as on the effectiveness of migration policy (de Haas et al., 2014, pp. 14-15; 2015, p. 12).

Some of indexes on immigration policy restrictiveness are characterised by relative higher level of detail of the analysis. In some research, results are classified for various groups of migrants and type of migration. For example, the main advantage of the indexes of immigration policy restrictiveness by Ortega \& Peri (2009, pp. 26-27) is the distinction of the immigration rules and laws for migrants and asylum seekers. In other project - in the IMPIC database, asylum seekers, economic migrants (low-skilled and highly-skilled), illegal and legal migrants and others were included (Schmid \& Helbing, 2016, pp. 26-27). Especially, these detailed research may be a useful tool to analyse the selectivity in migration (including immigration) policy and its restrictiveness, as well as to analyse effects, reasons and determinants of the migration flows of various groups of migrants. These projects will also improve understanding of migration policy selectivity both in terms of nationality and skill levels in the future analyses.

Many authors (i.e. Ortega \& Peri, 2009; Rayp et al., 2017; Schmid \& Helbing, 2016) are also classified migration (including immigration) policy to many detailed areas of policies. Especially, the classification of the immigration policy areas allows to identify the main reasons of immigration: economic, social, humanitarian, cultural and historical.

\section{Discussion}

Different definitions of migration (including immigration) policy and their components can influence various results of the analyses. Based on these differences, the literature on this subject indicates that direct comparison of the individual indexes (e.g. by correlation analysis) is impossible and would constitute a simplified approach (Schmid \& Helbing, 2016, p. 10).

Additionally, despite the different subject scope of indexes, the literature concluded that the indexes related to a single area of migration policy or groups of migrants etc. should be employed in empirical analyses. Furthermore, as de Haas \& Czaika (2013, p. 495) pointed the concept of national migration policy 
is difficult to define because various regulations are implemented for different groups of migrants.

Migration policy and changes in restrictiveness of this policy should be analysed in terms of various areas of migration policy or different groups of migrants (de Haas \& Czaika, 2013, p. 495). Internal contradictions within migration policy tool (e.g. act) are a 'rule', because the individual migration policy tool should be analysed in terms of specific area of migration policy or group of migrants. It also leads to a conclusion that many countries adopt different and contradictory migration policy aims (de Haas et al., 2014, pp. 7-8).

\section{Conclusion}

The indexes of migration (including immigration) restrictiveness are based on various concept of this policy. In particular, some of the research on migration policy restrictiveness are based on migration policy and other only on immigration policy. However, all the indexes of migration (including immigration) restrictiveness are based on de jure migration laws and regulations measures adopted by states (on the national level). Some of them are also related to international regulations, especially those associated with membership in the European Union.

The most of indexes of migration (including immigration) policy restrictiveness are based on a set of coded questions relating to these policies. The exception is the overall Migration Policy Index $\left(\mathrm{MPI}^{\mathrm{C}}\right)$ and its the three sub-indexes. The calculations of the three sub-indexes were based on a Bayesian-state space model. The overall Migration Policy Index $\left(\mathrm{MPI}^{\mathrm{C}}\right)$ was calculated as arithmetic mean of all the values of three sub-indexes. The second exception is the DEMIG database. DEMIG is especially based on descriptive statistics. However, the particular changes of migration policy were coded only to one area of migration policy. It needs to be also stressed that, the main differences between the indexes of migration (including immigration) policy restrictiveness are also related to the system of coding adopted in a given research. Additionally, the most of the research on migration (including immigration) policy restrictiveness are included data on absolute level of these policies, as opposed to DEMIG project and indexes by Ortega \& Peri (2009).

The main difference among indexes on migration policy is various areas of this policy that adopted by individual researchers. Both in the DEMIG project and research conducted by Rayp et al. (2017) the following areas of migration policy were included: legal entry and stay and integration. Additionally, the DEMIG database is also included the two areas of migration policy: border control and emigration. Concerning to the indexes of immigration restrictiveness, it needs to be stressed that, most of them are based on entry and stay regulations. Additionally, some of them entry and stay rules are classified for various groups of migrants or other areas of immigration policy (i.e. family re- 
union, economic (labour) migration, immigration control, political rights of immigrants and regulations concerning the access to nationality).

The possible application of indexes in other studies is especially related to the time and geographical scope of these indexes. Most of the data on migration policies is available mainly for the developed countries, the majority of which belongs to the OECD or the European Union. Coded data on relative changes in migration policies comes from 1945 (mostly in the years 1945-2013). However, for most countries the data is available since the 1980s. The possible application of indexes in other studies is also related to their level of detail. Certainly, the all of the analysed indexes may be a useful tool to perform the qualitative and quantitative study. However, some of them allow for the long-term analysis and other for short-term study. Some of indexes on immigration policy restrictiveness are characterised by relative higher level of detail of the analysis. Additionally, in some research, results are classified for various groups of migrants and type of migration.

Generally, the indexes of immigration policy restrictiveness may serve as extension and improvement in the organisation and collection of data on immigration policy. Consequently, projects may encourage to carry out the studies on effects and causes of international migration policies, as well as of studies that aimed to explain how the immigration policy affects migration flows. Finally, the indexes and projects are useful for policy makers, sociologists, economists, lawyers and others scholars, as well as may be an inspiration for other studies on migration policy.

\section{References}

Beine, M., Boucher, A., Burgoon, B., Crock, M., Gest, J., Hiscox, M., McGovern, P., Rapoport, H., Schaper, J., \& Thielemann, E. (2016). Comparing immigration policies: an overview from the IMPALA database. International Migration Review, 50(4). doi:10.1111/imre.12169.

Bjerre, L., Helbling, M., Römer, F., \& Zobel, M. (2016). The immigration policies in comparison (IMPIC) dataset: technical report. WZB Discussion Paper, VI 2016-201.

Castles, S. (2006). The factors that make and unmake migration policies. International Migration Review, 38(3). doi:10.1111/j.1747-7379.2004.tb00222.x.

Cheng, J.L.C. (1984). The role of cross-national research in organizational inquiry: a review and proposal. Academy of Management, 1. doi:10.5465/ AMBPP.1984.4978264.

Czaika, M., \& de Haas, H. (2013). The effectiveness of immigration policy. Рориlation and Development Review, 39(3). doi:10.1111/j.1728-4457.2013.00613.x.

de Haas, H., \& Czaika, M. (2013). Measuring migration policies: some conceptual and methodological reflections. Migration and Citizenship, 1(2).

de Haas, H., Natter, K., \& Vezzoli, S. (2014). Compiling and coding migration policies: insights from the Demig Policy database, IMI Working Papers, 87. 
de Haas, H., Natter, K., \& Vezzoli, S. (2015). Conceptualizing and measuring migration policy change. Comparative Migration Studies, 3(1). doi:10.1186/ s40878-015-0016-5.

Duszczyk, M. (2008). Wyzwania polskiej polityki migracyjnej a doświadczenia międzynarodowe. In P. Kaczmarczyk, \& M. Okólski (Eds.), Polityka migracyjna jako instrument promocji zatrudnienia i ograniczania bezrobocia. Warszawa: Ośrodek Badań nad Migracjami Uniwersytetu Warszawskiego.

Duszczyk, M. (2014). Ewolucja polskiej polityki migracyjnej w zakresie migracji zarobkowych po 1 maja 2004 r. Studia BAS, 4(40).

Fondazione Rodolfo Debenedetti. (2019). Mission. Retrieved 15.05.2019 from http://www.frdb.org.

Fumagalli, S., \& Boeri, T. (2009). Inventory of migration policies (1990-2005): reforms and index on strictness of migration policy. Retrieved 20.05.2019 from http://www.frdb.org.

Gest, J., Boucher, A., Challen, S., Burgoon, B.M., Thielemann, E., Beine, M., McGovern, P., Crock, M., Rapoport, H., \& Hiscox, M. (2014). Measuring and comparing immigration, asylum and naturalization policies across countries: challenges and solutions. Global Policy, 5(3). doi:10.1111/1758-5899.12132.

Hatton, T.J. (2004). Seeking asylum in Europe. Economic Policy, 19(38). doi:10.1111/j.1468-0327.2004.00118.x.

Hatton, T.J. (2009). The rise and fall of asylum: what happened and why. The Economic Journal, 119(535). doi:10.1111/j.1468-0297.2008.02228.x.

Helbling, M., Bjerre, L., Römer, F., \& Zobel, M. (2017). Measuring immigration policies: the IMPIC database. European Political Science, 16(1). doi:10.1057/eps.2016.4.

International Migration Institute. (2019). DEMIG policy data. Retrieved 08.05.2019 from https://www.imi.ox.ac.uk.

International Organization for Migration. (2018). World migration report 2018. Retrieved 08.05.2019 from https://www.iom.int.

Mayda, A.M., \& Patel, K. (2004). OECD countries migration policies changes: appendix to international migration: a panel data analysis of economic and non-economic determinant. Retrieved 15.05.2019 from https://sites.google.com/a/ georgetown.edu/annamariamayda.

MIPEX. (2015). Migrant integration policy index 2015. Retrieved from http:// www.mipex.eu.

Ortega, F., \& Peri, G. (2009). The causes and effects of international migrations: evidence from OECD countries 1980-2005. NBER Working Paper, 14833. doi:10.3386/wl4833.

Rayp, G., Ruyssen, I., \& Standaert, S. (2017). Measuring and explaining cross-country immigration policies. World Development, 95. doi:10.1016/j. worlddev.2017.02.026.

Schmid, S.D., \& Helbing, M. (2016). Validating the immigration policies in comparison (IMPIC) dataset. WZB Discussion Paper, VI 2016-202. 
Skeldon, R. (2010). Managing migration for development: is circular migration the answer. Whitehead Journal of Diplomacy and International Relations, 11(1).

\section{Acknowledgements}

Author contributions: author has given an approval to the final version of the article.

Funding: this research was funded by the Poznan University of Economics and Business, Institute of Economics, Department of Macroeconomics and Development Research statutory sources (no. 51112-1-32) and grants for young scientists and PhD students (no. 5113-1-394). 


\section{Appendix}

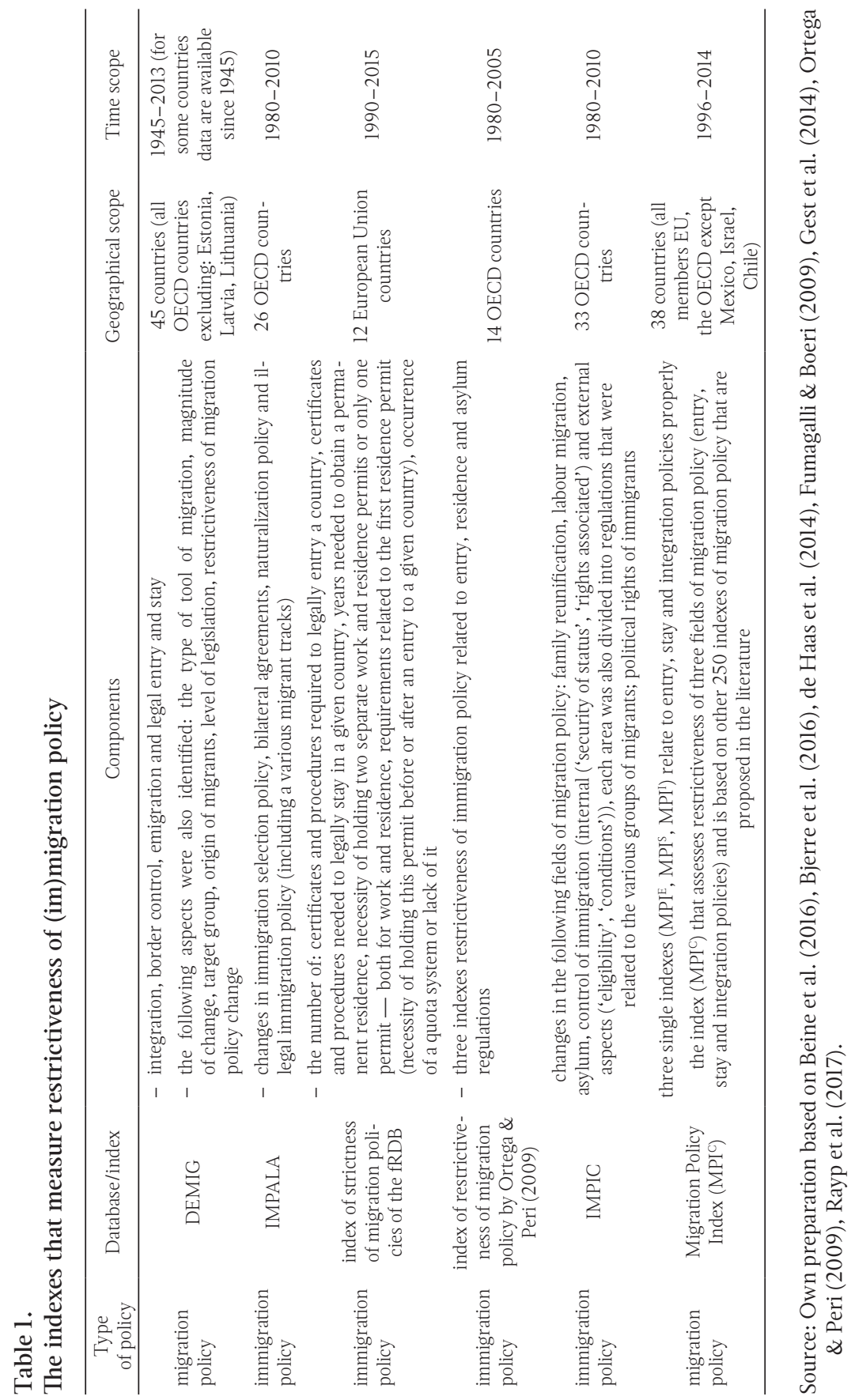




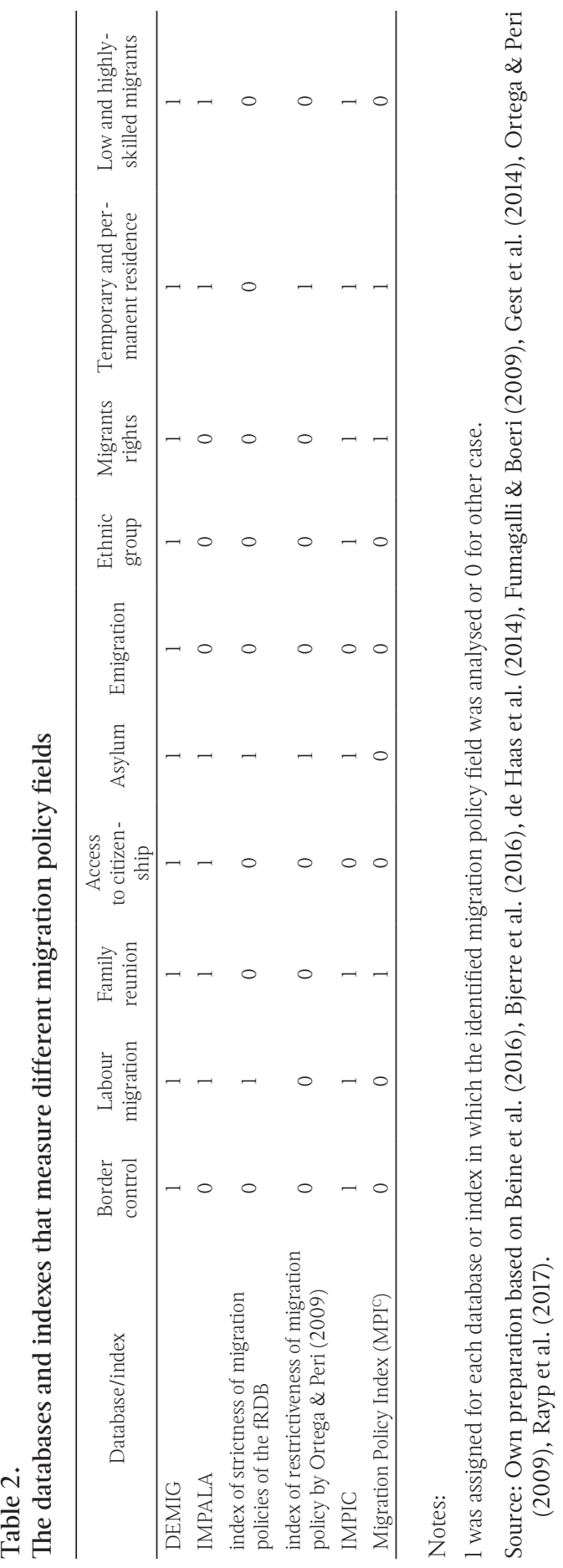


